\section{Degradation of Resin Composites in a Simulated Deep Cavity}

Luana Gonçalves, Cristiane Mariote Amaral, Laiza Tatiana Poskus, José

Guilherme Antunes Guimarães, Eduardo Moreira da Silva
Analytical Laboratory of Restorative Biomaterials - LABiom-R, Dental School, UFF - Fluminense Federal University, Niterói, RJ, Brazil

Correspondence: Prof. Dr. Eduardo Moreira da Silva, Rua Mário Santos Braga, $n^{\circ} 30$ - Campus Valonguinho, Centro, 24040-110 Niterói, RJ, Brasil. Tel.: +55-21-2629-9832. e-mail: emsilva@vm.uff.br
The aim of this study was to analyze the sorption and solubility of a nanofilled (Filtek Z350) and a midifilled (Filtek P60) resin composite in oral environment-like substances, in a simulated deep cavity. A cylindrical cavity prepared in a bovine incisor root was incrementally filled with resin composites. The obtained resin composite cylinders were cut perpendicularly to the axis to obtain 1-mm-thick discs that were divided into fifteen groups $(n=5)$ according to depth $(1,2,3,4$ and $5 \mathrm{~mm})$ and immersion media (distilled water - DW, artificial saliva - AS and lactic acid - LA). The sorption and solubility were calculated based on ISO 4049:2000. Additionally, the degree of conversion (DC\%) was calculated by FT-IR spectroscopy. Data were analyzed using multifactor analysis of variance (MANOVA) followed by Tukey's HSD post-hoc test and linear regression analysis ( $\alpha=0.05$ ). The DC\% was higher for the midifilled resin composite and was negatively influenced by cavity depth $(p<0.05)$. The nanofilled resin composite presented higher sorption and solubility than did the midifilled $(p<0.05)$. The immersion media influenced the sorption and the solubility as follows: $L A>A S>D W,(p<0.05)$. Both phenomena were influenced by cavity depth, with the sorption and solubility increasing from 1 to $5 \mathrm{~mm}(p<0.05)$. The degradation of resin composite restorations may be greater in the deepest regions of class II restorations when the composite is exposed to organic acids present in the oral biofilm (lactic acid).
Key Words: resin composites, degree of conversion, sorption, solubility.

\section{Introduction}

Resin composites are some of the most used materials in the field of esthetic restorative dentistry due to their potential to mimic the esthetic nuances of dental tissues and the on-demand polymerization reaction, which allows the clinicians to re-build the missing tooth anatomy due to caries or trauma (1). This class of restorative material is generally composed of a polymeric matrix of dimethacrylate monomers (Bis-GMA, BisEMA, UDMA or TEGDMA), a filler particle system and a silane agent that couples the filler particles and bonds them with the methacrylate links of the polymeric matrix (1). The result of this mechanism is an improvement in the material's mechanical properties.

In addition to improving the mechanical properties, the resistance to degradation in the devastating oral environment is also crucial for increasing the clinical life of resin composite restorations (2-4). Thus, several studies have analyzed the in vitro effect of immersion media on the sorption and solubility of different kinds of resin composites or dental resins, using immersion media such as distilled water (5-7), artificial saliva $(6,8,9)$, ethanol (10), $\mathrm{NaOH}$ (11) and organic acids produced by oral biofilm (6). Distler and Kröncke (12) showed in vivo that lactic acid represents 70\% of the organic acids present in the human oral biofilm and that this acid had a steeper increase greater than those of propionic and acetic acids after sucrose rinsing. Based on this, it is reasonable to speculate that during sugar insult, the bacteria present in the human oral biofilm, e.g., S. mutans, would increase the production of lactic acid, principally in areas where the buffer action of saliva is less effective and where the oral biofilm is adherent to the composite restoration surfaces, i.e., proximal areas. Thus, studies about the action of this acid on resin composites may increase the knowledge about resin composite degradation in the oral environment.

The sorption phenomenon in resin composites is a diffusion-controlled mechanism that causes chemical degradation due to the release of residual monomers and filler-polymeric matrix debonding. Solubility is reflected by the amount of leachable unreacted monomers. It is well accepted that both phenomena reflect the degradation mechanism of resin composite, leading to several drawbacks, such as weakening of the mechanical properties, formation of microcracks, plasticization of the polymeric matrix and a decrease in wear resistance, among others $(13,14)$.

In general, studies that have analyzed the sorption and solubility of resin composites based their methods on ISO 4049:2000(E), which establishes the evaluation of both phenomena using disc-shaped specimens with a $1.0 \mathrm{~mm}$ thickness. However, after taking into account the clinical practice, it is easy to imagine that the behavior of resin composites in the deepest regions of class II cavities, i.e., proximal surfaces, where the hygiene habits are difficult 
and where the action of organic acids produced by the oral biofilm could be more intense, may be somewhat different from that obtained in disc-shaped specimens that are 1 $\mathrm{mm}$ thick. Therefore, the purpose of the present study was to analyze the effect of oral environment-like substances (distilled water, artificial saliva and lactic acid) on the degradation (sorption and solubility) of a nanofilled and a midifilled resin composite in a simulated deep cavity. The research hypotheses were: 1 . nanofilled resin composite would present higher sorption and solubility than the midifilled one, 2. the sorption and solubility would be higher when the resin composites are immersed in lactic acid; and 3. there is a positive correlation between cavity depth and degradation (sorption and solubility).

\section{Material and Methods}

The characteristics of resin composites used in the present study are depicted in Table 1. All the resin composite specimens used in the experimental protocol were lightactivated from the top of the class I cavity model by using a quartz-tungsten-halogen unit (Optilux 501, Kerr, Danbury, CT, USA) employing an irradiance of $650 \mathrm{~mW} / \mathrm{cm}^{2}$ for 20 s monitored by a radiometer (model 100; Demetron Inc. Danbury, CT, USA).

\section{Degradation - Sorption (Sp) and Solubility (SI)}

The experimental setup is shown in Figure 1. A root $14 \mathrm{~mm}$ long, obtained from a bovine incisor, had the external surface ground to eliminate irregularities and was longitudinally sectioned to obtain two halves (Isomet 1000; Buehler, Lake Bluff, IL, USA). The root halves were externally lubricated with petroleum oil and fixed at the apex with epoxy resin. After the epoxy resin polymerization, a cylindrical class I cavity model $(\varnothing=5 \mathrm{~mm}$ and $\mathrm{h}=6 \mathrm{~mm})$ was prepared following the root canal, from the cervical to the apical region of the sectioned root, using a diamond bur (\#4054, KG Sorensen, SP, Brazil) on a high-speed hand piece fixed in a special sample aligning device. The cavity depths were controlled by using a digital caliper (MPI/E-101; Mitutoyo, Tokyo, Japan).

Fifteen cylinders of each resin composite were obtained by filling the class I cavity model with six individually light-activated increments of each material. After that, the cylinders were sectioned perpendicularly to the axis into five disc-shaped 1-mm-thick specimens. Since the diamond disc used to cut de specimens was $0.2-\mathrm{mm}$ thick, each resin composite cylinder produced only five disc-shaped specimens. The discs were manually polished on both sides using 4000-grit SiC paper to eliminate irregularities. Fifteen experimental groups for each resin composite were produced, $(n=5)$ : five depths $(1,2,3,4$ and $5 \mathrm{~mm}$ ) vs. immersion media [distilled water - DW, artificial saliva - AS - $(\mathrm{KCl}, \mathrm{NaCl}, \mathrm{MgCl}, \mathrm{CaCl}$, Nipagin, CNC, Sorbitol and deionized water - neutral $\mathrm{pH}$ ) and lactic acid - LA $0.1 \mathrm{M}-\mathrm{pH}=4]$.

The discs were individually placed in vials, transferred to a desiccator containing freshly dried silica gel and maintained in an oven at $37 \pm 1{ }^{\circ} \mathrm{C}$. The discs were weighed daily using an analytical balance (AUW 220; Shimadzu, Tokyo, Japan) until a constant mass $\left(m_{1}\right)$ was attained, i.e., the disc mass variation was less than $\pm 0.01 \mathrm{mg}$. The thickness and the diameter of the discs were measured at four points, using a digital caliper (MPI/E-101; Mitutoyo) and the volume $(\mathrm{V})$ was calculated in $\mathrm{mm}^{3}$. The discs were then immersed in $10 \mathrm{~mL}$ of each experimental medium, and were weighed daily until sorption equilibrium was

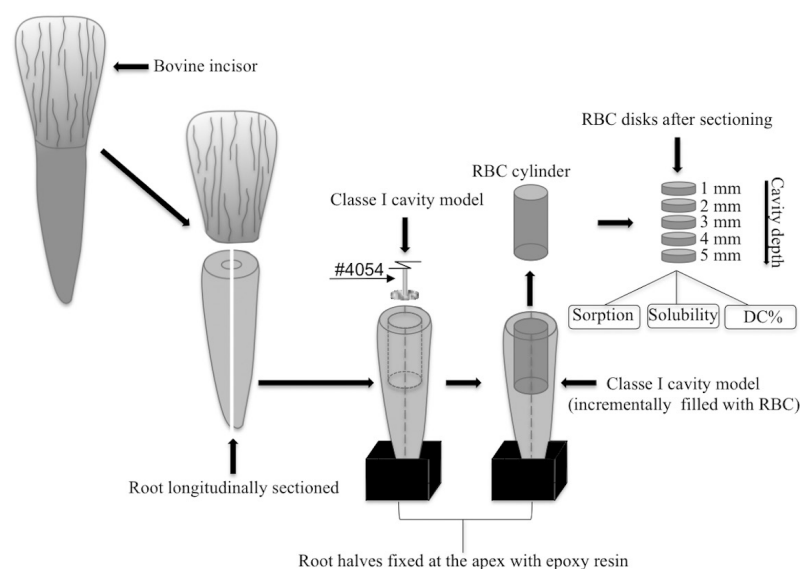

Figure 1. Schematic drawing of the experimental setup.

Table 1. Characteristics of resin composites used in the present study.

\begin{tabular}{ccc}
\hline Resin composite & Composition* $^{*}$ & Manufacturer \\
\hline Filtek P 60 & Filler: 61 vol\% silica/zirconia filler with mean particle size of 0.6 $\mu \mathrm{m}$. & $3 \mathrm{M}$ ESPE, \\
(A3 shade) & Polymeric matrix: Bis-GMA, Bis-EMA, UDMA TEGDMA & St Paul, \\
Midifilled & & MN, USA \\
Filtek Z350 & Filler: 59.5 vol\% combination of aggregated zirconia/silica cluster filler with primary particles size of 5-20 & $3 \mathrm{M}$ ESPE, \\
(A3B shade) & nm, and nonagglomerated 20 nm silica filler. Polymeric matrix: Bis-GMA, Bis-EMA, UDMA TEGDMA & St Paul, \\
Nanofilled & & \\
\hline
\end{tabular}

*As disclosed by the manufacturers. 
reached, [mass variation less than $\pm 0.01 \mathrm{mg}\left(\mathrm{m}_{2}\right)$ ]. Each experimental medium was changed every $24 \mathrm{~h}$. The discs were then placed in a desiccator containing freshly dried silica gel, transferred to an oven at $37 \pm 1^{\circ} \mathrm{C}$ and weighed daily until the mass variation was less than $\pm 0.01 \mathrm{mg}\left(\mathrm{m}_{3}\right)$.

The sorption (Sp) and solubility (SI) were obtained using the following equations $\left(\mu \mathrm{g} / \mathrm{mm}^{3}\right)$ :

$$
\begin{aligned}
& S p=\frac{m_{2}-m_{3}}{V} \\
& S I=\frac{m_{1}-m_{3}}{V}
\end{aligned}
$$

\section{Degree of Conversion - DC\%}

Spectra of one unpolymerized disc of each resin composite $(\emptyset=5$ and $h=1 \mathrm{~mm})$ were recorded using a FTIR spectrometer (Alpha-P/Platinum ATR Module; Bruker Optik GmbH, Ettlingen, Germany) operating with 120 scans and at a resolution of $4 \mathrm{~cm}^{-1}$. For each resin composite, five additional cylinders were produced as described for the sorption and solubility evaluation. After being cut into five discs $1 \mathrm{~mm}$ thick, the FT-IR spectra of the $\vec{s}$ polymerized specimens were recorded as performed for the unpolymerized increments on the surfaces corresponding to the occlusal face (one spectrum for each disc). The $\mathrm{DC} \%$ was calculated from the ratio between the height of absorbance peaks of the aliphatic $\mathrm{C}=\mathrm{C}$ bond $\left(1638 \mathrm{~cm}^{-}\right.$ 1) to the aromatic $\mathrm{C}=\mathrm{C}$ bond $\left(1608 \mathrm{~cm}^{-1}\right)$ obtained from the polymerized and unpolymerized specimens, by the following equation:

$\mathrm{DC} \%=100 \times\left[1-\left(\mathrm{R}_{\text {polymerized }} / \mathrm{R}_{\text {unpolymerized }}\right)\right]$, where $R=$ peak at $1638 \mathrm{~cm}^{-1} /$ peak at $1608 \mathrm{~cm}^{-1}$

\section{Statistical Analysis}

The obtained data were analyzed using Statgraphics

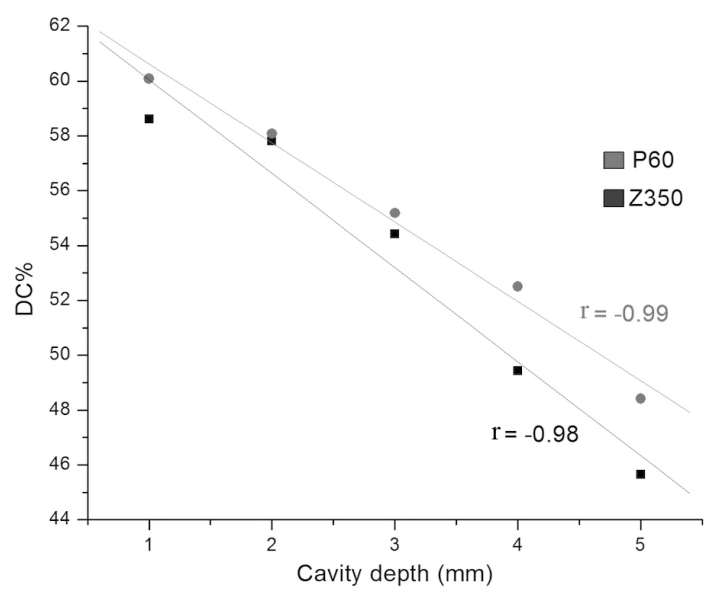

Figure 2. Regression lines (linear model) of DC\% vs. cavity depth.
Centurion XVI software (STATPOINT Technologies, Inc, Warrenton, VA, USA). First, the normal distribution of the errors and the homogeneity of variances were checked by Shapiro-Wilk's test and Levene's test. Based on these preliminary analyses, the $\mathrm{DC} \%$, sorption and solubility data were separately analyzed by multifactor analysis of variance (MANOVA) and Tukey's HSD post-hoc test. Data were also subjected to regression analysis, with the degree of conversion as the dependent variable and the cavity depth as the independent variable. All analyses were performed at a significance level of $\alpha=0.05$.

\section{Results}

MANOVA showed statistical significance for DC\% as function of the independent factors resin composite: $P 60>Z 350,(p=0.0027)$ and cavity depth $(\mathrm{mm}): 1=2>3>4>5$, $(p<0.05)$. The double interaction of resin composite vs. cavity depth was not significant $(p=0.3667)$. For both resin composites, the regression analysis showed a strong negative correlation between cavity depth and DC\% (Fig. 2).

With respect to sorption, MANOVA showed statistically significant difference for the independent factors resin composites: $P 60<Z 350(p<0.05)$, media immersion: LA $>$ AS $>$ DW $(p<0.05)$ and cavity depth $(\mathrm{mm}): 1=2=3<4<5$ $(p<0.05)$, as well as for the double interaction of resin composite $v$ s. media immersion ( $p=0.0022)$. No significance was found for the interactions of resin composite vs. cavity depth ( $p=0.1410)$, media immersion vs. cavity depth $(p=0.2938)$ and resin composite vs. media immersion vs. cavity depth $(p=0.1697)$. The results of the Tukey's HSD test are shown in Table 2. All groups presented sorption values statistically higher at the $5 \mathrm{~mm}$ depth $(\mathrm{p}<0.05)$.

Regarding the solubility, MANOVA showed statistically significant difference for the independent factors resin composites: $\mathrm{P} 60<\mathrm{Z350},(\mathrm{p}<0.05)$, media immersion: LA $>A S>D W, \quad(p<0.05)$ and cavity depth: $1=2<3=4<5$, $(p<0.05)$. All the interactions were found to be statistically significant $(p<0.05)$. The results of the Tukey's HSD test are shown in Table 3. Irrespective of media immersion, both resin composites presented an increase in solubility as a function of depth, with a significant increase at $5 \mathrm{~mm}$ $(p<0.05)$. For the midifilled resin composite immersed in DW, the solubility increased significantly after $2 \mathrm{~mm}(\mathrm{p}<0.05)$. For the other groups, this significant increase started after the $3 \mathrm{~mm}$ depth $(\mathrm{p}<0.05)$.

\section{Discussion}

The dental scientific literature presents vast information about the sorption and the solubility suffered by resin composites $(5,9)$. However, currently there is no available data regarding these phenomena in resin composites applied in the deepest layers of restorations and exposed 
to oral fluids. Clinically, the gingival margins of class II preparations can be $6.3 \mathrm{~mm}$ from the occlusal surface (15). Consequently, the resin composites applied in this region will probably be exposed to low irradiance from a light-curing unit. Moreover, recent studies have shown that organic acids in the oral biofilm increased the sorption and solubility of resin composites and resin cements (16). Thus, it seems to be of some relevance to study the sorption and solubility of resin composites in a simulated deep cavity to increase the knowledge about the degradation of this class of restorative material.

Clinically, the degradation of resin composites will happen only if the material is exposed to the oral fluids, e.g., free surfaces of any restoration and proximal surfaces of Class II restorations. Based on this, the use of a Class I cavity model in the present study could be misunderstood. The rationale for this was to obtain standardized disc specimens to measure sorption and solubility as closely as possible to ISO4049 standard.

Since bovine dentin presents similar structure to human dentin (17), in the present study the resin composites were applied in a cavity prepared in a bovine incisor root. This approach was used to mimic as closely as possible the effect of light transmission through dentin on resin composite polymerization in a clinical situation.

Sorption and solubility are influenced by the principal phases of resin composite, i.e., polymeric matrix and filler particle $(9,10,18)$. This was the rationale for choosing Z350 (nanofilled) and P60 (midifilled) resin composites to conduct this study. According to the manufacturer (3M ESPE, St Paul, MN, USA), both materials have the same monomers (Bis-GMA, Bis-EMA, UDMA and TEGDMA) in their polymeric matrix, differing only by the filler particle systems. Consequently, the present results were viewed only upon the influence of filler particle size on both responses (sorption and solubility).

Since the nanofilled resin composite presented a higher sorption and solubility than the midifilled resin composite, the first research hypothesis of the present study was accepted. Two paths can explain the worse result presented by the nanofilled resin composite. The first may be linked to a possibly greater amount of water accumulated along the greater filler particle-polymeric matrix interfaces derived from the non-agglomerated $20 \mathrm{~nm}$ silica filler $(9,19)$. This great amount of water may have increased the release of ions from the filler particle surfaces or even contributed to the hydrolysis of the ester bonds of the silane-coupling agent, which could facilitate filler particle debonding (20). The second path was most probably influenced by the lower DC\% attained by this composite resin. Although both analyzed resin composites have the same polymeric matrix, the filler particles of nanofilled are in the nanoscale (Table 1). During activation, the light that passes through the resin composite structure is scattered by the filler particles with a mean size close to half the wavelength of the light unit. Based on this, it is possible that the non-agglomerated silica nanoparticles with mean size of $20 \mathrm{~nm}$ may have caused a light-scattering effect in nanofilled composite. Thus, the light intensity might have been attenuated and its DC\% decreased.
Table 2. Means (SD) of sorption $\left(\mu \mathrm{g} / \mathrm{mm}^{3}\right)$ for all tested group

\begin{tabular}{|c|c|c|c|c|c|c|}
\hline \multirow{3}{*}{$\begin{array}{l}\text { Cavity } \\
\text { depth } \\
(\mathrm{mm})\end{array}$} & \multicolumn{6}{|c|}{ Resin composite } \\
\hline & \multicolumn{3}{|c|}{ P60 } & \multicolumn{3}{|c|}{$\mathrm{Z} 350$} \\
\hline & DW & AS & LA & DW & AS & LA \\
\hline 1 & $\begin{array}{c}26.4 \\
\text { (1.9) Аa }\end{array}$ & $\begin{array}{c}28.4 \\
(3.0) \mathrm{Aa}\end{array}$ & $\begin{array}{c}31.9 \\
(1.4) \mathrm{Aa}\end{array}$ & $\begin{array}{c}27.7 \\
(3.0) \mathrm{Aa}\end{array}$ & $\begin{array}{c}32.2 \\
(2.1) \mathrm{Aa}\end{array}$ & $\begin{array}{c}33.3 \\
(2.6) \mathrm{Aa}\end{array}$ \\
\hline 2 & $\begin{array}{c}28.0(3.5) \\
\mathrm{ABa}\end{array}$ & $\begin{array}{c}27.3 \\
\text { (3.3) Aa }\end{array}$ & $\begin{array}{c}32.0 \\
(3.8) \mathrm{Aa}\end{array}$ & $\begin{array}{c}29.8 \\
(2.7) \mathrm{ABa}\end{array}$ & $\begin{array}{c}32.0 \\
(2.1) \mathrm{Aa}\end{array}$ & $\begin{array}{c}32.2 \\
\text { (3.3) Aa }\end{array}$ \\
\hline 3 & $\begin{array}{c}28.9(3.6) \\
\text { ABab }\end{array}$ & $\begin{array}{c}25.1 \\
(2.9) \mathrm{Aa}\end{array}$ & $\begin{array}{c}31.5 \\
(0.9) \mathrm{Ab}\end{array}$ & $\begin{array}{c}30.4 \\
(4.0) \mathrm{ABa}\end{array}$ & $\begin{array}{c}34.6 \\
(2.8) \mathrm{ABa}\end{array}$ & $\begin{array}{c}34.4 \\
(3.9) \mathrm{Aa}\end{array}$ \\
\hline 4 & $\begin{array}{c}32.5 \\
(1.1) \mathrm{Ba}\end{array}$ & $\begin{array}{c}30.1 \\
(1.2) \mathrm{ABa}\end{array}$ & $\begin{array}{c}30.0 \\
(1.0) \mathrm{ABa}\end{array}$ & $\begin{array}{c}33.1 \\
(2.4) \mathrm{ABa}\end{array}$ & $\begin{array}{c}35.3 \\
(3.5) \mathrm{ABa}\end{array}$ & $\begin{array}{c}37.4 \\
(2.9) \mathrm{ABa}\end{array}$ \\
\hline 5 & $\begin{array}{c}33.5 \\
(2.8) \mathrm{Ba}\end{array}$ & $\begin{array}{c}35.0 \\
(3.6) \mathrm{Ba}\end{array}$ & $\begin{array}{c}35.5 \\
(2.9) \mathrm{Ba}\end{array}$ & $\begin{array}{c}36.1 \\
(4.5) \mathrm{Ba}\end{array}$ & $\begin{array}{c}40.7 \\
(3.8) \mathrm{Ba}\end{array}$ & $\begin{array}{c}42.9 \\
(4.8) \mathrm{Ba}\end{array}$ \\
\hline
\end{tabular}

In columns, values with identical capital letters are similar (Tukey HSD, $p>0.05$ ) In rows, for each resin composite, values with identical low case letters are similar (Tukey HSD, $p>0.05$ ).

Table 3. Means (SD) of solubility $\left(\mu \mathrm{g} / \mathrm{mm}^{3}\right)$ for all tested group

\begin{tabular}{|c|c|c|c|c|c|c|}
\hline \multirow{3}{*}{$\begin{array}{l}\text { Cavity } \\
\text { depth } \\
(\mathrm{mm})\end{array}$} & \multicolumn{6}{|c|}{ Resin composite } \\
\hline & \multicolumn{3}{|c|}{ P60 } & \multicolumn{3}{|c|}{$\mathrm{Z} 350$} \\
\hline & DW & AS & LA & DW & AS & LA \\
\hline 1 & $\begin{array}{c}4.5 \\
(0.3) \mathrm{Aa}\end{array}$ & $\begin{array}{c}5.9 \\
(0.7) \mathrm{Ab}\end{array}$ & $\begin{array}{c}6.4 \\
(0.4) \mathrm{Ab}\end{array}$ & $\begin{array}{c}5.4 \\
(0.4) \mathrm{Aa}\end{array}$ & $\begin{array}{c}6.8 \\
(0.8) \mathrm{Ab}\end{array}$ & $\begin{array}{c}7.1 \\
(0.7) \mathrm{Ab}\end{array}$ \\
\hline 2 & $\begin{array}{c}6.1 \\
(0.7) \mathrm{Ba}\end{array}$ & $\begin{array}{c}6.3 \\
(0.3) \mathrm{ABa}\end{array}$ & $\begin{array}{c}7.0 \\
(0.4) \mathrm{Aa}\end{array}$ & $\begin{array}{c}5.3 \\
(0.6) \mathrm{ABa}\end{array}$ & $\begin{array}{c}6.6 \\
(1.0) \mathrm{Ab}\end{array}$ & $\begin{array}{c}7.8 \\
(0.6) \mathrm{Ac}\end{array}$ \\
\hline 3 & $\begin{array}{c}6.0 \\
(0.8) \mathrm{Ba}\end{array}$ & $\begin{array}{c}6.9 \\
(0.7) \mathrm{Bab}\end{array}$ & $\begin{array}{c}7.4 \\
(1.4) \mathrm{Ab}\end{array}$ & $\begin{array}{c}6.5 \\
(0.5) \mathrm{BCa}\end{array}$ & $\begin{array}{c}8.1 \\
(0.6) \mathrm{Bb}\end{array}$ & $\begin{array}{c}9.0 \\
(0.4) \mathrm{Bb}\end{array}$ \\
\hline 4 & $\begin{array}{c}7.3 \\
(0.5) \mathrm{CDa}\end{array}$ & $\begin{array}{c}7.2 \\
(0.7) \mathrm{Ba}\end{array}$ & $\begin{array}{c}7.8 \\
(1.1) \mathrm{Ba}\end{array}$ & $\begin{array}{c}7.0 \\
(0.4) \mathrm{Ca}\end{array}$ & $\begin{array}{c}\text { 6.7, } \\
\text { (1.4) } \mathrm{Aa}\end{array}$ & $\begin{array}{c}10.0 \\
(0.5) \mathrm{Bb}\end{array}$ \\
\hline 5 & $\begin{array}{c}8.1 \\
(0.8) \mathrm{Da}\end{array}$ & $\begin{array}{c}9.1 \\
(0.4) \mathrm{Cb}\end{array}$ & $\begin{array}{c}10.4 \\
(1.0) \mathrm{Cc}\end{array}$ & $\begin{array}{c}9.9 \\
(1.1) \mathrm{Da}\end{array}$ & $\begin{array}{c}12.6 \\
(1.3) \mathrm{Cb}\end{array}$ & $\begin{array}{c}14.4 \\
(0.9) \mathrm{Cc}\end{array}$ \\
\hline
\end{tabular}

In columns, values with identical capital letters are similar (Tukey HSD, p > 0.05). In rows, for each resin composite, values with identical low case letters are similar (Tukey HSD, $p$ > 0.05). 
The values of sorption and solubility ranged from 25.1 to $42.9 \mu \mathrm{g} / \mathrm{mm}^{3}$ and from 4.5 to $14.4 \mu \mathrm{g} / \mathrm{mm}^{3}$, respectively. When comparing these values with those established in ISO 4049 standard, some interesting conclusions may be drawn. With respect to sorption, two values were greater than the maximum sorption established by the standard (40 $\mu \mathrm{g} / \mathrm{mm}^{3}$ ), one of them achieved after immersion in lactic acid. Analyzing the solubility data, eleven values exceeded the maximum solubility established in the standard (7.5 $\mu \mathrm{g} / \mathrm{mm}^{3}$ ), with six values achieved after immersion in lactic acid. Moreover, most of the values of sorption and solubility after immersion in lactic acid were statistically or numerically higher than those obtained after immersion in distilled water. Thus, it is clear that the worst-case scenarios in the present study were found after immersion in lactic acid. When combined with the results of the statistical analysis, these findings lead to the acceptance of the second research hypothesis.

This strong effect of lactic acid on sorption and solubility can be linked to two aspects. First, presence of the $-\mathrm{OH}$ and $-\mathrm{COOH}$ functional groups may favor the establishment of hydrogen bonds with the polar sites of the dimethacrylate monomers in the resin composite s polymeric matrixes, i.e., $-\mathrm{OH}$ - in Bis-GMA, -0- in TEGDMA and Bis-EMA and -NH- in UDMA (6). The consequence of this hydrogen bonding is an increase in acid uptake by the matrix. Second, the low pH (=4) of lactic acid may have acted on the polymeric matrixes by catalysis of the ester groups from the dimethacrylate monomers (21). The hydrolysis of these ester groups may produce alcohols and carboxylic molecules that may accelerate degradation by lowering the $\mathrm{pH}$ inside the matrix (6). Additionally, the low $\mathrm{pH}$ may also have caused erosion of the filler surfaces, accelerating their debonding or increase the release of ions from their surfaces $(22,23)$. Both phenomena may have contributed to an increase in solubility.

The sorption and the solubility after immersion in artificial saliva were higher than in distilled water, with one value of sorption $\left(40.7 \mu \mathrm{g} / \mathrm{mm}^{3}\right)$ and three values of solubility $\left(8.1 ; 9.1\right.$ and $\left.12.6 \mu \mathrm{g} / \mathrm{mm}^{3}\right)$ surpassing the maximum values established in ISO 4049. Since in oral cavity the resin composites are exposed to saliva rather than water, these findings are noteworthy. Analyzing Si-filler-based experimental composites, Soderholm et al. (20) found that artificial saliva produced a higher leaching of filler particles than distilled water and claimed that this was due to a greater ion exchange at filler surfaces produced by the salt solution simulating saliva. Since the resin composites analyzed in the present study have Sibased filler in their compositions, it seems reasonable to claim that the same phenomenon took place here. The result of this can be a higher solubility. On the other hand, it is possible that this filler leaching could have created more sites of polymeric matrix, which favored the establishment of a high level of hydrogen bonding with artificial saliva, thereby increasing sorption (6).

In the present study, the cavity depth influenced the sorption and the solubility. Thus, the third research hypothesis was accepted. For solubility, the influence of cavity depth was more remarkable, with a significant increase in solubility starting at $2 \mathrm{~mm}$ for P60/DW and at 3 $\mathrm{mm}$ for the other groups. Moreover, in terms of percentage, this increase ranged from 54.2 to $93.0 \%$ from the first to the fifth millimeter. The explanation for this behavior is based on the strong negative correlation found between DC\% and cavity depth (Fig. 2). It is well known that a lower degree of conversion leads to lower solubility $(9,24)$. Thus, it is clear that the progressive decrease in $\mathrm{DC} \%$ with increasing cavity depths had a negative influence on the solubility. On the other hand, even taking into account that sorption was also influenced by the cavity depth, Table 2 shows that the sorption values were significantly higher only at $5 \mathrm{~mm}$, with percentage increases from 11.3\% (P60/LA) to 28.8\% (Z350 / LA) from the first to the fifth millimeter. This behavior clearly shows that the chemical structure of the monomers in polymeric matrix is the prevailing factor on sorption phenomena, instead of DC\% (25).

Summarizing the findings discussed here, it was proved that the degradation (sorption and solubility) of resin composites was higher in the specimens obtained from the deepest layers of a cylindrical class I cavity model. Additionally, the degradation was significantly higher in the nanofilled resin composite and increased after immersion in lactic acid.

\section{Resumo}

0 objetivo deste estudo foi analisar a absorção e a solubilidade de uma resina composta nanopartículada (Filtek Z350) e de uma hibrida (Filtek P60) em substâncias simuladoras do ambiente oral em um modelo de cavidade profunda. Uma cavidade cilindrica, construida em uma raiz de um incisivo bovino, foi preenchida incrementalmente com as resinas compostas. Os cilindros obtidos foram seccionados perpendicularmente ao eixo para obtenção de discos com $1 \mathrm{~mm}$ de espessura, que foram divididos em 15 grupos $(n=5)$ de acordo com a profundidade $(1,2,3,4$ e $5 \mathrm{~mm}$ ) e o meio de imersão (água destilada - $A D$, saliva artificial - SA e ácido lático - $\mathrm{AL}$ ). $\mathrm{A}$ absorção e a solubilidade foram calculadas com base na norma ISO 4049:2000(E). Adicionalmente, o grau de conversão $(\mathrm{GC} \%)$ foi calculado através de espectroscopia FT-IR. Os dados obtidos foram analisados usando análise de variância multifatorial, teste de Tukey HSD e análise de regressão linear $(\alpha=0,05)$. A resina composta hibrida apresentou o maior grau de conversão, sendo este influenciado pela profundidade da cavidade $(p<0,05)$. A resina composta nanopartículada apresentou maiores valores de absorção e solubilidade $(p<0,05)$. 0 meio de imersão influenciou a absorção e a solubilidade: $A L>S A>A D(p<0,05)$. Ambos os fenômenos foram influenciados pela profundidade da cavidade, com os valores aumentando de 1 para $5 \mathrm{~mm}(p<0,05)$. A degradação de restaurações de resinas compostas pode ser maior em regiões profundas de restaurações classe Il e quando o material é exposto à ácidos orgânicos produzidos pelo biofilme oral (ácido lático). 


\section{References}

1. Ferracane JL. Resin composite - state of the art. Dental Mater $2011 ; 27: 29-38$.

2. Bourbia M, Ma D, Cvitkovitch DG, Santerre JP, Finer Y. Cariogenic bacteria degrade dental resin composites and adhesives. J Dental Res 2013;92:989-994.

3. Munchow EA, Ferreira AC, Machado RM, Ramos TS, Rodrigues-Junior $\mathrm{SA}$, Zanchi $\mathrm{CH}$. Effect of acidic solutions on the surface degradation of a micro-hybrid composite resin. Braz Dent J 2014;25:321-326.

4. Giannini M, Di Francescantonio M, Pacheco RR, Cidreira Boaro LC, Braga RR. Characterization of water sorption, solubility, and roughness of silorane- and methacrylate-based composite resins. Oper Dent 2014;39:264-272.

5. Sideridou I, Tserki V, Papanastasiou G. Study of water sorption, solubility and modulus of elasticity of light-cured dimethacrylatebased dental resins. Biomaterials 2003;24:655-665.

6. da Silva EM, Goncalves L, Guimaraes JG, Poskus LT, Fellows CE. The diffusion kinetics of a nanofilled and a midifilled resin composite immersed in distilled water, artificial saliva, and lactic acid. Clin Oral Investig 2011;15:393-401.

7. Gajewski VE, Pfeifer CS, Froes-Salgado NR, Boaro LC, Braga RR. Monomers used in resin composites: degree of conversion, mechanical properties and water sorption/solubility. Braz Dent J 2012;23:508-514.

8. Almeida GS, Poskus LT, Guimaraes JG, da Silva EM. The effect of mouthrinses on salivary sorption, solubility and surface degradation of a nanofilled and a hybrid resin composite. Oper Dent 2010;35:105-111.

9. Silva EM, Almeida GS, Poskus LT, Guimaraes JG. Relationship between the degree of conversion, solubility and salivary sorption of a hybrid and a nanofilled resin composite. J Appl Oral Sci 2008;16:161-166.

10. Sideridou ID, Karabela MM, Bikiaris DN. Aging studies of light cured dimethacrylate-based dental resins and a resin composite in water or ethanol/water. Dental Mater 2007;23:1142-1149.

11. Sarkar NK. Internal corrosion in dental composite wear. J Biomed Mater Res 2000;53:371-380.

12. Distler W, Kroncke $A$. The acid pattern in human dental plaque. J Dent Res 1983;62:87-91.

13. Ruttermann $\mathrm{S}$, Kruger $\mathrm{S}$, Raab WH, Janda R. Polymerization shrinkage and hygroscopic expansion of contemporary posterior resin-based filling materials - a comparative study. J Dent 2007;35:806-813.
14. Mayworm CD, Camargo SS Jr., Bastian FL. Influence of artificial saliva on abrasive wear and microhardness of dental composites filled with nanoparticles. Journal of Dentistry 2008;36:703-710.

15. Price RB, Derand $T$, Sedarous $M$, Andreou $P$, Loney RW. Effect of distance on the power density from two light guides. J Esthet Dent 2000;12:320-327.

16. Marghalani HY. Sorption and solubility characteristics of self-adhesive resin cements. Dental Mater 2012;28:e187-e198.

17. Camargo MA, Marques MM, Cara AA. Morphological analysis of human and bovine dentine by scanning electron microscope investigation. Archives of Oral Biology 2008;53:105-108.

18. Cornelio RB, Wikant A, Mjosund H, Kopperud HM, Haasum J, Gedde UW, et al.. The influence of bis-EMA vs bis-GMA on the degree of conversion and water susceptibility of experimental composite materials. Acta Odontol Scand 2014;72:440-447.

19. Kalachandra S, Wilson TW. Water sorption and mechanical properties of light-cured proprietary composite tooth restorative materials. Biomaterials 1992;13:105-109.

20. Soderholm KJ, Mukherjee R, Longmate J. Filler leachability of composites stored in distilled water or artificial saliva. J Dental Res 1996;75:1692-1699.

21. Nishiyama N, Suzuki K, Yoshida H, Teshima H, Nemoto K. Hydrolytic stability of methacrylamide in acidic aqueous solution. Biomaterials 2004;25:965-969.

22. Rahim TN, Mohamad D, Md Akil H, Ab Rahman I. Water sorption characteristics of restorative dental composites immersed in acidic drinks. Dental Mater 2012;28:e63-e70.

23. Gusmao GM, De Queiroz TV, Pompeu GF, Menezes Filho PF, Silva CH. The influence of storage time and $\mathrm{pH}$ variation on water sorption by different composite resins. Indian J Dent Res 2013;24:60-65.

24. Berger SB, Palialol AR, Cavalli V, Giannini M. Characterization of water sorption, solubility and filler particles of light-cured composite resins. Braz Dent J 2009;20:314-318.

25. Ferracane JL. Hygroscopic and hydrolytic effects in dental polymer networks. Dental Mater 2006;22:211-222.

Received May 14, 2014 Accepted October 12, 2014 